\title{
GROWTH RATE, LEPTIN AND IGF-1 CONCENTRATIONS, CARCASS AND MEAT CHARACTERISTICS OF EGYPTIAN BUFFALO MALE CALVES IN RELATION TO FAT SUPPLEMENTED RATION
}

\author{
S.M. Salem, Amal K. El-Asheeri and Rehab Nagy \\ Department of Animal Production, Faculty of Agriculture, University of Cairo, \\ 12613, Giza, Egypt
}

\section{SUMMARY}

This study comprised two experiments (Exp); the first to study the growth curve of the Egyptian buffalo calves, and the second to study the effect of supplying fattening ration with protected fat on growth and carcass traits.

In the $1^{\text {st }}$ Exp., 10 growing buffalo male calves ( 8 months of age) with initial body weight of $115.0 \pm 4.0 \mathrm{~kg}$ were used. Calves were fed concentrate feed mixture (CFM) and rice straw (RS) based on their weights. Monthly weighing were executed to plot the growth curve and to determine the average daily gain (ADG). Blood samples were collected every three months to determine the concentration of IGF-1 and Leptin. In the $2^{\text {nd }}$ Exp., another eight buffalo calves (about $256 \mathrm{~kg}$ ) were divided into two equal groups. The $1^{\text {st }}(G 1)$ was served as a control fed on CFM and RS, while the $2^{\text {nd }}$ group (G2) was fed similar ration of G1 supplemented with commercial calcium salts of fatty acids $(0.13 \%$ of the BW) to calculate $A D G$, fattening period (FP) and final $B W(F B W)$. Blood samples were collected monthly to determine IGF-1 and Leptin hormones. At BW of approximately $400 \mathrm{~kg}$ calves were slaughtered for studying carcass traits and meat quality. Best ribs (9, 10 and $11^{\text {th }}$ ribs) were separated from the left side of the carcass to calculate bone, lean, fat tissues (\%) and to determine chemical and physical traits of meat.

Results of the $1^{\text {st }}$ Exp indicated that BW of buffalo calves increased from $115.0 \pm$ 4.0 to $357 \pm 2.7 \mathrm{~kg}$ throughout the period from 8 to 24 month of age. ADG increased gradually up to the $23^{\text {rd }}$ month of age before decreasing to $0.433 \mathrm{~kg}$ at the $24^{\text {th }}$ month. $I G F-1$ concentration increased with age progress (from $41.0 \pm 2.8 \mathrm{ng} / \mathrm{ml}$ to 368.0 $\pm 10.0 \mathrm{ng} / \mathrm{ml}$ ) before decreasing to $273.0 \pm 63.0 \mathrm{ng} / \mathrm{ml}$ at the $24^{\text {th }}$ month of age. Leptin concentration between the $8^{\text {th }}$ and $20^{\text {th }}$ month of age was $3.4 \pm 0.3 \mathrm{ng} / \mathrm{ml}$ increased to $5.08 \pm 1.01 \mathrm{ng} / \mathrm{ml}$ between the $20^{\text {th }}$ and $24^{\text {th }}$ month of age.

In the $2^{\text {nd }}$ Exp, BW and FP were similar in G1 and G2 being $385.0 \pm 7.3$ vs. 397.0 $\pm 4.9 \mathrm{~kg}$ and $243.0 \pm 6.0$ vs. $252.0 \pm 11.0$ day. Feeding buffalo calves on diet supplemented with fat had no significant effect on $A D G(0.508 \pm 0.01$ vs. $0.564 \pm 0.03$ $\mathrm{kg})$ and feed conversion $(13.1 \pm 1.16 \mathrm{vs} .11 .9 \pm 0.4 \mathrm{DM} / \mathrm{Kg}$ gain) being similar in $\mathrm{G} 1$ and $G 2$, respectively. During fattening period $I G F-1$ in $G 1$ was insignificantly higher $(255.7 \pm 29.0 \mathrm{ng} / \mathrm{ml})$ than of $\mathrm{G} 2(204.2 \pm 17.0 \mathrm{ng} / \mathrm{ml})$. Meanwhile, Leptin concentration was higher $(P<0.05)$ in $G 2(5.0 \pm 0.6 \mathrm{ng} / \mathrm{ml})$ than in $G 1(3.9 \pm 0.8$ $\mathrm{ng} / \mathrm{ml})$. There were no significant differences between $G 1$ and $G 2$ concerning hot

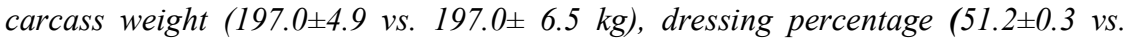
$49.8 \pm 1.1 \%)$ and boneless meat percentage $(35.6 \pm 0.8$ vs. $38.3 \pm 1.4 \%)$, respectively.

Issued by The Egyptian Society of Animal Production 
Physical and chemical traits of meat were similar in both groups, except intramuscular fat which was higher $(P<0.05)$ in $G 2$.

In conclusion growth curve of Egyptian buffalo calves between 8 and 24 months showed exponential increase up to $23^{\text {rd }}$ month of age before showing descending trend. This was accompanied with high level of IGF-1 concentration, while Leptin concentration in the peripheral blood started to increase from the $20^{\text {th }}$ month of age. Supplying ration with protected fat during fattening period (256 to $400 \mathrm{~kg}$ ) had no effect on growth, carcass, and meat traits.

Keywords: Buffalo calves, growth, IGF-1, Leptin, carcass traits, physical and chemical traits of meat

\section{INTRODUCTION}

Growth rate of ruminants is the main factor determines the total gain and red meat yield. Total body gain is a combination of increasing of lean mass and fat deposition. Lean mass is affected by genotype (Rehfeldt et al., 2004), micro environment (TePas et al., 2004), sex (Tokuda et al., 2007), age (Appa Rao et al., 2009), nutrition (Owens and Gardner, 1999) and the balance among hormones control metabolism (Squires, 2003).

Role of IGF-1 in growth process is well defined. Increasing IGF-1 concentration is associated with the increase in body weight and growth rate in cattle and sheep (Cronje, 2002 and Barkawi et al., 2009). IGF-1 regulate growth of skeletal muscle and multiple tissues (Brandt et al., 200₹) by stimulating amino acids uptake of muscle cells (Shimizu et al., 1986), inhibiting proteolysis (Fryburg, 1994) and improving efficiency of feed utilization (Yilmaz et al., 2004). These actions are supported by the findings of Anderson et al. (1988) who reported a positive relationship between IGF-1 and area of Longissimus dorsi muscle.

In ruminants, increasing Leptin concentration in the peripheral blood plasma stimulates fat accumulation (Chilliard et al., 2005, Nkrumah et al., 2007 and Tokuda et al., 2008). Leptin concentrations starts to increase significantly with puberty- hood (Zieba et al., 2005). Leptin acts as a regulator of lipid reserves via its effect on food intake and energy metabolism (Agrawel et al., 2009), which affects increasing body weight and body composition (Chilliard et al., 2005 and Zieba et al., 2005).

Buffaloes play a considerable role in bridging the gap of red meat in Egypt. Egyptian buffaloes were reported to have lower average daily gain compared to cattle (El-Naggar, 1998), leading to higher cost of producing $1 \mathrm{~kg}$ gain. Improving obtained ADG of buffaloes could be achieved through nutritional and management manipulations. Supplementing fat to beef cattle and sheep rations can be an effective strategy to increase energy density of the animal's diet (Hess et al., 2008). Increasing energy intake is expected to increase growth rates (Nour El-Din et al., 2009), and to improve carcass characteristics (Gigli et al., 1993) of ruminants.

Many trials were conducted to study the effect of replacing part of the concentrate mixture with protected fat (El-Bedawy et al., 2004 and Abo-Donia and Ibrahim, 2008) to improve growth and meat quality traits, while the results indicated no effect on studied traits. On the other hand, feeding buffalo calves on protected fat (Ca-SFA) as a source of energy during the finishing period improved meat production and quality (Abo-Donia and Ibrahim, 2008). Access of energy also contributes in 
increasing boneless meat percentage (Gigli et al., 1993 and; Bendary et al., 1994) and increasing fat deposition, which may have impact on the economics of producing 1 $\mathrm{kg}$ gain.

Up to the knowledge of the authors there is lack of data describing the profile of IGF-1 and Leptin hormones throughout the growth stages of Egyptian buffaloes, and there are few studies concerning the effect of supplementing ration with protected fat on growth and carcass traits.

In the light of the available data, the present work aimed at: 1- studying the growth curve of buffalo male calves in relation to IGF-1 and Leptin concentrations and studying the effect of supplementing rations of fattened male buffalo calves with protected fat on the growth features, carcass and meat traits, in relation to IGF-1 and Leptin hormones in peripheral blood plasma.

\section{MATERIALS AND METHODS}

This study was conducted at the Agriculture Experimental Station, Faculty of Agriculture, Cairo University during the period from January 2008 to May 2009.

\section{Experimental Design:}

The present study comprises two experiments, the $1^{\text {st }}$ to describe the growth features of buffalo male calves in relation to IGF-1 and Leptin hormonal profile, and the $2^{\text {nd }}$ to study the growth and carcass traits in relation to IGF-1 and Leptin concentrations during fattening period.

\section{The first experiment (Growing phase):}

Data of growth of 10 growing buffalo male calves were collected to plot the growth curve from 8 to 24 month of age. The initial body weight of the experimental calves was $115.0 \pm 4.0 \mathrm{~kg}$. Calves were housed tied in a semi open yard and fed on concentrate feed mixture (CFM) and rice straw (RS) based on their live body weight (BW) (NRC requirements, 2000). Concentrate feed mixture (14\% protein) composed of $50 \%$ yellow corn, $20 \%$ wheat bran, $20 \%$ cotton seed cake, $5 \%$ soybean cake, $5 \%$ salts and minerals mixture. Feeding and watering were practiced twice daily. Throughout the course of the experiment, calves were weighed monthly after about $16 \mathrm{hr}$ fasting to plot growth curve and determine average daily gain (ADG).

\section{The second experiment (Fattening phase):}

Another eight buffalo male calves were divided into two equal groups. The body weight of the two groups was differed non-significantly being $256.0 \pm 3.5$ and 255.7 $\pm 2.7 \mathrm{~kg}$ for the first $(\mathrm{G} 1)$ and second (G2) groups, respectively. G1 was served as a control, where fed according to their BW on CFM and RS, while G2 was fed similar to $\mathrm{G} 1$ in addition to commercial calcium salts of fatty acids (CSFA, Ibelac ${ }^{\circledR}$ IBEX international, Egypt). The amount of offered CSFA was $0.13 \%$ of the BW as recommended by Villalobos et al. (2007). The residual feed was weighed daily to calculate the feed conversion. Around $400 \mathrm{~kg} \mathrm{BW}$ calves were slaughtered according to the Islamic rules to study carcass traits and meat quality.

\section{Slaughter Procedure:}

Calves were slaughtered after fasting period of $18 \mathrm{hr}$. After bleeding and removing hide, head and legs, calves were eviscerated and section down through 
vertebral column into two halves. The left side of each carcass was separated between the $8^{\text {th }}$ and $9^{\text {th }}$ rib into two quarters; fore and hind. Both quarters were weighed before dissecting into wholesale cuts (bone and meat). The fore quarter was separated into six primal cuts (Fore shank, shoulder, fore ribs, flat ribs, brisket and neck), while hind quarter was separated also into six cuts including hind shank, round, sirloin, thin-flank, and thick flank and fillet according to German meat cuts (Weniger et al., 1963) to record weights of each cut. Best ribs (9, 10 and $11^{\text {th }}$ ribs) were separated from the left side and weighed fresh. Best ribs were chilled at $4^{\circ} \mathrm{C}$ for $24 \mathrm{hr}$, afterwards; they were weighed again before dissecting into bone, lean and fat tissues. L-dosi samples were stored at $-20^{\circ} \mathrm{C}$ till the time of chemical and physical analyses.

\section{Physical and Chemical Traits:}

Chemical analysis of the rib cut samples was performed using food Scan ${ }^{\mathrm{TM}}$ Pro meat analyzer (Foss Analytical A/S, Model 78810, Denmark). According to the manufacturers ${ }^{\mathrm{TM}}$ instructions about 50-100 gm of raw meat (obtained from the $9^{\text {th }}$ rib) were minced and put in the meat analyzer cup to determine the percentages of moisture, protein, fat and collagen.

Cooking loss was determined using two cubes of meat (about $100 \mathrm{gm}, \mathrm{W}_{1}$ ). The samples were boiled in saline $(0.09 \% \mathrm{Nacl})$ for 45 minutes, then left to cool at room temperature. Sample was re-weighed $\left(\mathrm{W}_{2}\right)$ to calculate the cooking loss percentage as the difference between two weights divided by $\mathrm{W}_{1}$ multiplied by 100 (Sami, 2001). The cooked samples were used to determine the shear force values $(\mathrm{kg})$. Samples were kept in refrigerator at $4-5^{\circ} \mathrm{C}$ for about $12 \mathrm{hr}$, before estimating shear force using Instron Universal Testing Machine (Model 2519-105, USA). According to the manufacturer's instructions, six cores from each sample were taken using cylinder of 0.5 inch in diameter. Cores were removed parallel to the longitudinal orientation of muscle fibers. The machine was adjusted at crosshead speed of $200 \mathrm{~mm} / \mathrm{min}$ according to the recommendation of Shackelford et al. (1999).

Meat color was measured using Chroma meter (Konica Minolta, model CR 410, Japan) calibrated with a white plate and light trap supplied by the manufacturer. Color was expressed using the CIE L*, a*, and b* color system (CIE, 1976).

\section{Blood Sampling and Hormonal Assay:}

In the $1^{\text {st }}$ Exp, $10 \mathrm{ml}$ of blood samples were collected from the jugular vein in heparinized tube every three months up to the end of the experiment ( 24 months old), while in the $2^{\text {nd }}$ experiment blood samples $(10 \mathrm{ml})$ were collected monthly to determine IGF-1 and Leptin hormones in the peripheral blood plasma. Before morning feeding and watering, samples were collected, then centrifuged for plasma separation for 15 minutes at $3500 \mathrm{rpm}$. Harvested plasma was stored at $-20^{\circ} \mathrm{C}$ till the time of hormonal assay.

Leptin determination was performed by ELISA reader (BIO TEK ELX808), using Leptin ELISA kit sandwich (DRG Instruments GmbH, Germany) according to the manufacturer's guideline. The standard curve was between 0 and $100 \mathrm{ng} / \mathrm{ml}$. The sensitivity of the curve was reported to be $1.0 \mathrm{ng} / \mathrm{ml}$. The cross reaction of the antibody was found to be $100 \%$ with human Leptin, $<0.2 \%$ with rat and mouse Leptin and not detectable with other hormones. 
IGF-1 was assessed by radioimmunoassay technique (RIA) using readymade kits (Immunotech SAS -130 av. kit, France). The standard curve was between 0 and 1200 $\mathrm{ng} / \mathrm{ml}$. The analytical sensitivity was reported to be $2 \mathrm{ng} / \mathrm{ml}$. The cross reaction of the antibody with other hormones was found to be extremely low . The samples were determined in one run and the intra-assay variation coefficient was $6.3 \%$.

\section{Statistical Analysis:}

In experiment 1 , all values were expressed as means and standard errors (mean \pm S.E.), using the tabulate procedure of the statistical package for social science (SPSS 17.0). The Pearson's correlation test (between means) was used to calculate correlations between Leptin, IGF-1, and some growth traits. In experiment 2, data in percentages were transformed to the arcsine square-root to normalize error before analysis. The following model was used:

$\mathrm{Y}_{\mathrm{ij}}=\mu+\mathrm{T}_{\mathrm{i}}+\mathrm{e}_{\mathrm{ij}}$

Where

$\mathrm{Y}_{\mathrm{ij}}=$ the measured trait,

$\mu=$ the overall mean,

$\mathrm{T}_{\mathrm{i}}=$ effect of feeding $(\mathrm{i}=1,2 ; 1$ feed on CFM and 2=CFM plus protected fat), $\mathrm{e}_{\mathrm{ij}}=$ Random error.

\section{RESULTS AND DISSCUSION}

\section{Experiment 1:}

\section{Growth features of growing phase:}

Buffalo male calves showed an exponential increase in their BW from the $8^{\text {th }}$ to $23^{\text {th }}$ month of age, before showing a decrease trend during the last month of the experiment. During the course of the experiment, BW of the calves increased 2.3 times (from $115.0 \pm 4.0 \mathrm{~kg}$ to $357 \pm 2.7 \mathrm{~kg}$ ) (Fig. 1). The decrease in growth by the $24^{\text {th }}$ month of age may be due to approaching puberty of the experimental calves and starting the $2^{\text {nd }}$ phase of the growth curve (Sigmoid phase). This conclusion is supported by the findings of Abd El-Aziz (2006) on the Egyptian buffalo bulls reporting an increase in testosterone concentrations in blood plasma starting 19-20 month of age.

Average daily gain (ADG) showed a parallel trend to the growth curve; except the unexplainable decrease observed between 14 and 17 months of age. ADG increased gradually from 0.479 to $0.515 \mathrm{~kg}$ throughout the period from the $8^{\text {th }}$ to the $23^{\text {rd }}$ month of age and then decreased to $0.433 \mathrm{~kg}$ (about $90 \%$ of the initial ADG) during the $24^{\text {th }}$ month of age (Fig.1).

The obtained higher ADG during the period from 8 to 23 month of age compared to the $24^{\text {th }}$ month agrees with the results of Bendary et al. (1994) reporting similar trend. Also, came close to the previous reports of El-Ashry et al. (1996) and Bassiouni et al. (2000) reporting ADG between 494 and $529 \mathrm{~g}$ within the same age period.

The present result of growth curve agree with the findings of Mandal et al. (2003) and Nada (2003) indicating that the initial of sigmoid part of Buffaloes' growth curve occurred between 350 and $360 \mathrm{~kg} \mathrm{BW}$. 


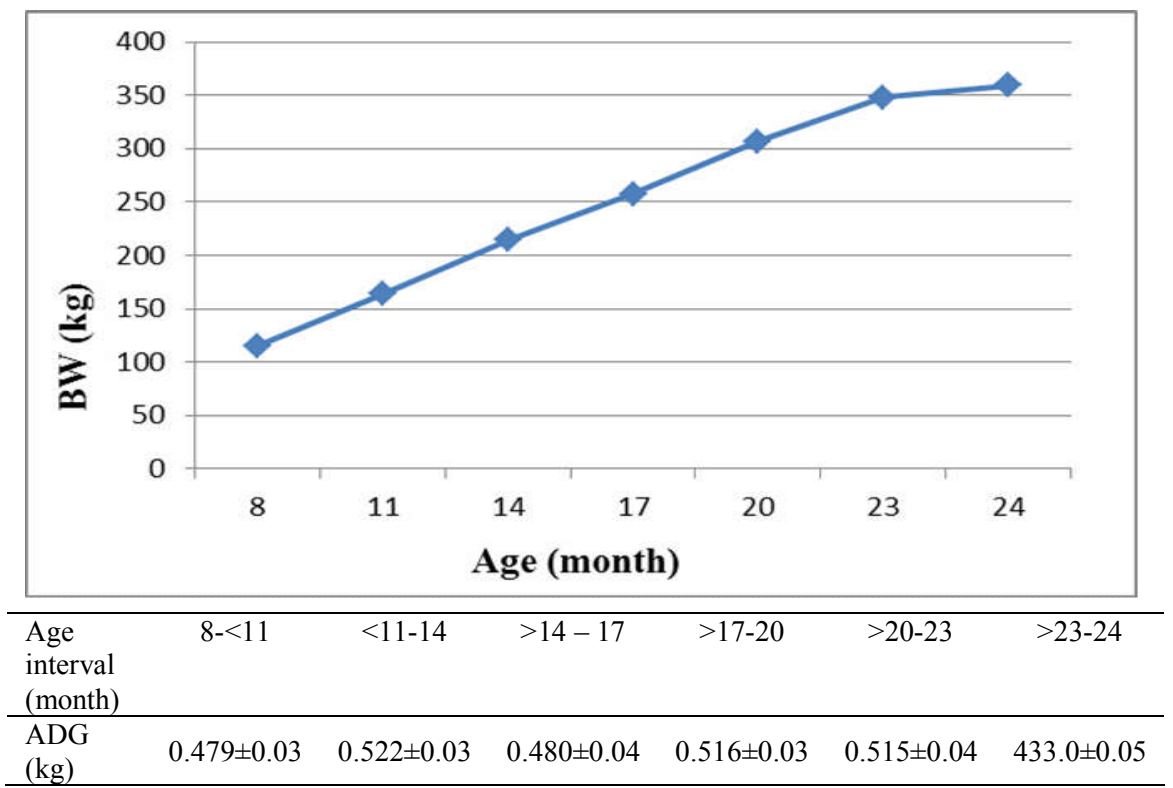

Figure 1. Growth curve and average daily gain (mean \pm SE) of growing buffalo calves from 8 to 24 months of age

Hormonal profile:

IGF-1 concentration:

Concentration of IGF-1 during the experimental period averaged $170.9 \pm 33.0$ $\mathrm{ng} / \mathrm{ml}$ with a range of 41.4 to $368.3 \mathrm{ng} / \mathrm{ml}$. The curve of IGF-1 concentration showed similar trend to the growth curve of the experimental calves. IGF-1 concentration increased gradually from the $8^{\text {th }}(41.0 \pm 2.8 \mathrm{ng} / \mathrm{ml})$ to the $23^{\text {th }}$ month $(368.0 \pm 10.0$ $\mathrm{ng} / \mathrm{ml}$ ) of age. Afterwards, IGF-1 concentration decreased to reach a value of $273.0 \pm$ $63.0 \mathrm{ng} / \mathrm{ml}$ at the $24^{\text {th }}$ month of age (Fig.2).

The present results indicated a positive correlation between body weight and IGF-1 $(\mathrm{P}<0.05)$ and negative correlation between IGF-1 and ADG (Table 1). The obtained correlation between IGF-1 and body weight (0.775) was higher than that reported by Baker et al. (1991) (0.38). Increasing IGF-1 concentration with age progress came in agreement with the findings of Lee et al. (1990) on bulls and steers of Belgian Blue and Holstein Friesian.

The obtained negative correlation between IGF-1 and ADG is supported by the findings of Connor et al. (2000) on Black Angus bulls reporting that high level of IGF-1 exhibited slower rate of gain. The authors reported that correlation coefficients between ADG and IGF-1 decreased with age progress being between -0.32 and 0.3. Negative correlation between IGF-1 and ADG may be due to fat deposition rather than protein synthesis, which observed with age progress (Shimizu et al., 1986).

The positive correlation between IGF-1 and BW is due to the role of IGF-1 in the regulation of growth of skeletal muscle and efficiency of feed utilization (Yilmaz et al., 2004). 


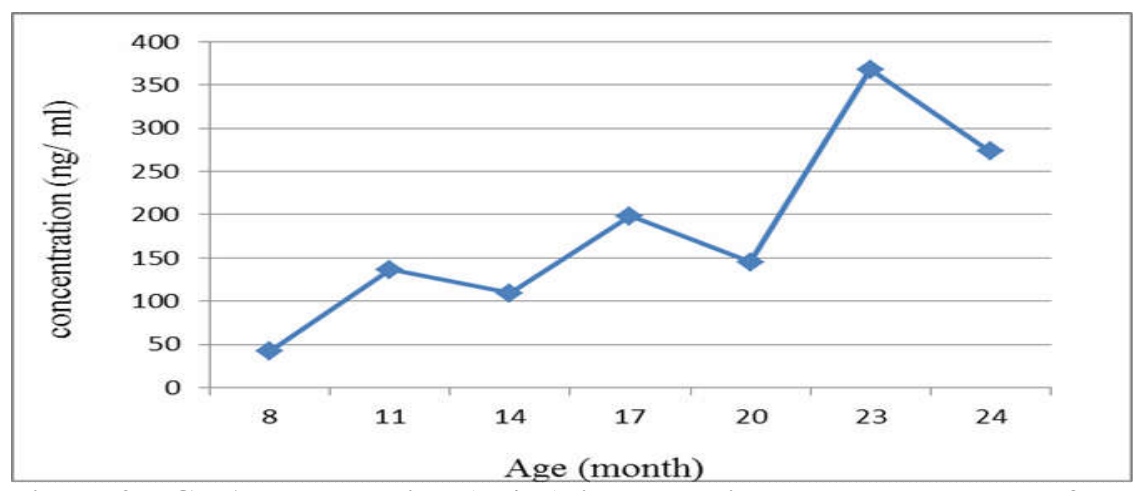

Figure 2. IGF-1 concentration $(\mathrm{ng} / \mathrm{ml})$ in the preipheral blood plasma of the Egyptian buffalo calves between 8 and 24 months of age

\section{Leptin concentration :}

Concentration of Leptin across the experimental period showed two distinct phases (Figure 3 ). The $1^{\text {st }}$ was between the $8^{\text {th }}$ and $20^{\text {th }}$ month of age, in which plasma Leptin was less than $4.0 \mathrm{ng} / \mathrm{ml}$ with an overall mean of $3.4 \pm 0.3 \mathrm{ng} / \mathrm{ml}$. During this period concentration of Leptin had almost constant trend. The $2^{\text {nd }}$ phase was between the $20^{\text {th }}$ and $24^{\text {th }}$ month of age, where Leptin concentration showed an exponential increase reaching $7.8 \pm 0.9 \mathrm{ng} / \mathrm{ml}$ with an average of $5.1 \pm 1.01 \mathrm{ng} / \mathrm{ml}$.

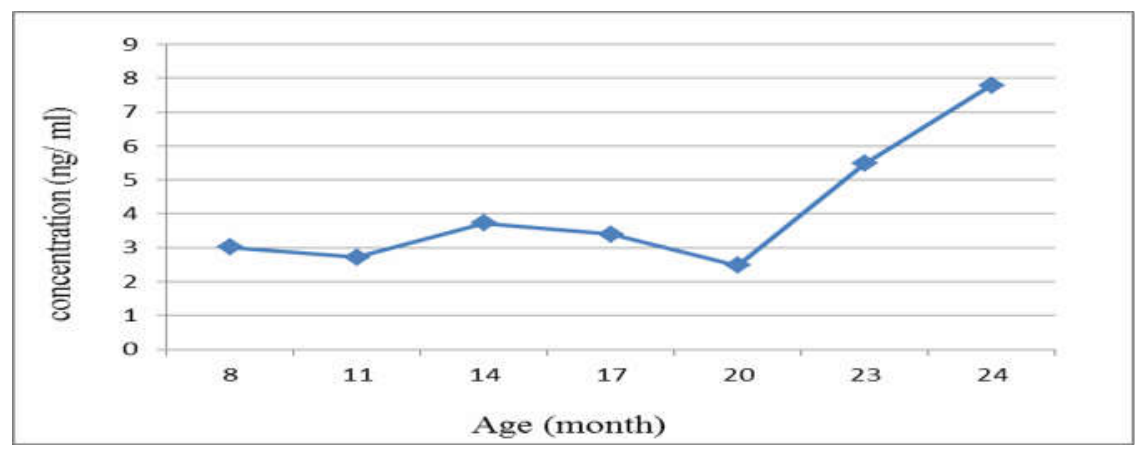

Figure 3. Concentration $(\mathrm{ng} / \mathrm{ml})$ of Leptin in the preipheral blood plasma of the Egyptian buffalo calves between 8 and 24 months of age

The increase in plasma Leptin concentration with advancement of age may reflect the increase of fat deposition due to approaching maturation (Block et al., 2003). This suggestion is supported in the light of the findings of Ragab et al. (1966) who reported that fat tissues in Egyptian buffalo bulls increased with age progress and started to increase from the $18^{\text {th }}$ month of age. Kawakita et al. (2001) also reported that increase in Leptin concentration was related to the deposit fat mass, which may be due to puberty approaching. This conclusion is supported by the findings of Thomas et al. (2002) reporting positive correlation between Leptin and testosterone in growing bulls.

The obtained results of Leptin concentration during the first growing phase (8-20 months of age) came close to the results of Thomas et al. (2002) and Daix et al. 
(2008) on growing Angus bulls, who found that the concentration of Leptin between 8 and 17 months of age was between 3.0 and $3.4 \mathrm{ng} / \mathrm{ml}$.

\section{Correlation coefficients:}

The present results indicated that there was a positive correlation between plasma Leptin and body weight, but negative with ADG (Table 1). The obtained positive correlation between body weight and serum concentration of Leptin came in agreement with the findings of Thomas et al. (2002) and Nkrumah et al. (2007). Also the negative relationship between Leptin and ADG agreed with findings of Altmann et al. (2006) on lambs, but disagreed with the findings of Nkrumah et al. (2007) who reported no correlation between Leptin and ADG.

The positive correlation between IGF-1 and Leptin agrees with the findings of Thomas et al. (2002) and Leon et al. (2004), while disagree with the findings of Brandt et al. (2007) who reported negative correlation between these two hormones.

Table 1. Correlation coefficients among BW, ADG, circulating concentrations of Leptin and IGF-1 in Egyptian buffalo calves from $8^{\text {th }}$ to $24^{\text {th }}$ of age

\begin{tabular}{lcccc}
\hline Variables & B.W(kg) & ADG $(\mathbf{g})$ & Leptin $(\mathbf{n g} / \mathbf{m l})$ & IGF-1 $(\mathbf{n g} / \mathbf{m l})$ \\
\hline BW $(\mathbf{k g})$ & 1 & -0.119 & 0.550 & $0.775^{*}$ \\
ADG (g) & & 1 & -0.390 & -0.099 \\
Leptin (ng/ml) & & & 1 & $0.696^{*}$ \\
IGF-1 (ng/ml) & & & & 1 \\
\hline
\end{tabular}

*The correlation was significant $(\mathrm{P}<0.05)$

\section{Experiment 2:}

Growth features during fattening period:

The obtained results indicated that there were no significant differences between G1 (control) and G2 (fed protected fat supplemented ration) regarding ADG, BW, FP and feed conversion. However, ADG and feed conversion was better in G2 than in G1. It is also of interest to point out that the total energy intake of G2 was nonsignificantly higher than G1 (Table. 2). This may be due to the higher level of Liptin (Figure 5), which primary decreased appetite and feed intake (Chilliard et al., 2005),

Table 2. Growth traits of Egyptian buffalo calves under control (G1) and fat supplementation feed (G2)

\begin{tabular}{llll}
\hline Traits & \multicolumn{1}{c}{ G1 } & G2 & $\begin{array}{c}\text { P } \\
\text { value }\end{array}$ \\
\hline Growth traits & & & \\
$\quad$ Initial body weight (kg) & $256.0 \pm 3.5$ & $255.7 \pm 2.7$ & 0.958 \\
Final body weight (kg) & $385.0 \pm 7.3$ & $397.0 \pm 4.9$ & 0.223 \\
Fattening period (day) & $243.0 \pm 6.0$ & $252.0 \pm 11.0$ & 0.581 \\
ADG (kg) & $0.508 \pm 0.01$ & $0.564 \pm 0.03$ & 0.212 \\
Feed intake / FP* & & & \\
Concentrate feed mixture (CFM) (Kg)/ FP & $1548.3 \pm 19$ & $1251.5 \pm 50.0$ & 0.052 \\
$\quad$ Protected fat (kg)/ FP. & & $119.2 \pm 3.6$ & \\
$\quad$ Rice straw (kg)/ FP. & $471.5 \pm 102$ & $531.9 \pm 15.0$ & 0.303 \\
$\quad$ Energy intake and feed conversion: & & & \\
Total energy kcal/calf/day. & $24134.9 \pm 128.0$ & $25493.6 \pm 1129$ & 0.227 \\
$\quad$ Feed conversion (DM/ kg gain) & $13.1 \pm 1.1$ & $11.9 \pm 0.4$ & 0.253 \\
\hline *FP: Fattening period & & &
\end{tabular}

*FP: Fattening period 
These results agreed with the findings of El-Bedawy et al. (1996) who found that supplementing the ration of Baladi bulls with $5 \%$ or $7.5 \%$ fat had no effect on BW. Also, agreed with the findings of Gassman et al. (2000) reporting no differences in growth efficiency between the control and calves fed ration supplemented with $2.5 \%$ rumen-protected CLA salt. Moreover, results of Nada (2003) and Gillis et al. (2004) indicated that ADG, dry matter intake and gain to fed ration did not affected by supplementing diets with $2-10 \%$ fats. On the contrast, El-Bedawy et al. (2004) reported that replacing part of energy of fattened calves with 4 and $8 \%$ ca-SF, improved ADG and final body weight.

The non-significant difference in ADG, BW and feed conversion in G1 and G2 may be due to the insignificant difference between the two studied groups in total energy intake. This is most probably attributed to the high residue in feed daily allowance in G2 compared to G1. Unexpected lower energy intake of G2 may be due to high energy content per feed unit (CFM+ CSFA), which represents heat load of animals when consuming all diet allowance.

Results of feed conversion agreed with the findings of Nada (2003) reporting that feeding buffalo calves on ration contained $10 \%$ fat had no effect on feed conversion, while disagreed with the findings of El-Bedawy et al. (1996) reporting better feed conversion of Baladi bulls fed on fat as a part of ration compared to those fed on the regular ration.

\section{IGF-1 concentration:}

Plasma concentration of IGF-1 was non-significantly less in G2 than in G1 (Figure 4). The overall mean of IGF-1 concentration during fattening period was $255.7 \pm 29.0 \mathrm{ng} / \mathrm{ml}$ and $204.2 \pm 17.0 \mathrm{in} \mathrm{G1}$ and G2, respectively. However the difference between the two groups was not significant $(50 \mathrm{ng} / \mathrm{ml})$. The nonsignificant difference may be attributed to the low number of the samples and the wide variation among individuals within group.

The low concentration of IGF-1 in G2 than in G1 may be due to increasing Leptien concentration (Figure 5), which had a negative correlation with IGF-1 (Table 3).

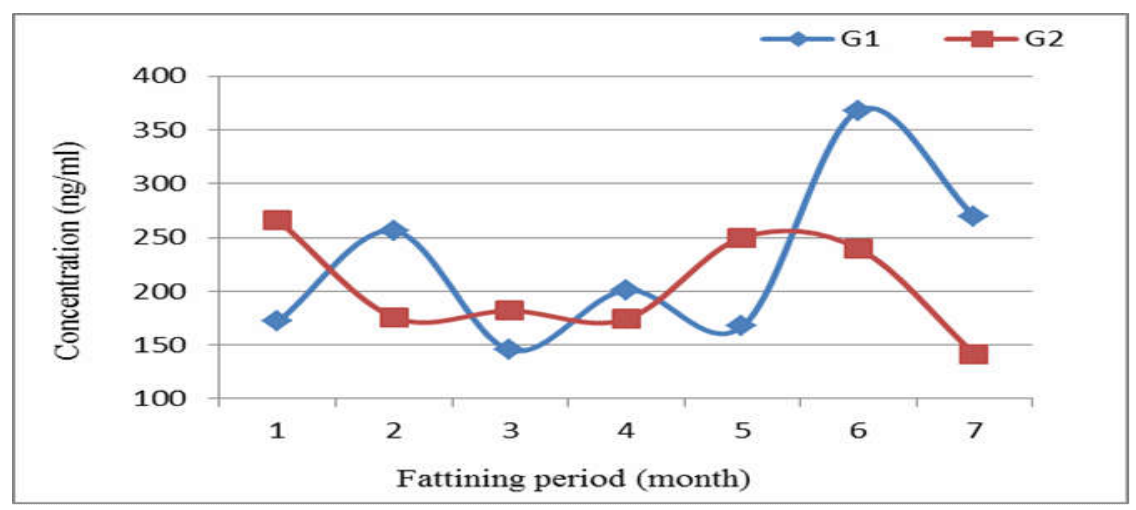

Figure 4. IGF-1 concentration ( $\mathrm{ng} / \mathrm{ml}$ ) in buffalo calves fed on concentrate feed mixture (G1) and concentrate feed mixture supplemented with protected fat (G2) 
The trend of the present results is in agreement with the results of Garcia et al. (2003) who reported that serum IGF-1 concentrations were less in heifers and lactating cows, fed on diet containing fat. On the opposite, Villalobos et al. (2007) revealed that feeding feedlot steers on fat supplemented diet had no effect on IGF-1 concentration compared to a control group. Increasing feed intake from rice straw in $\mathrm{G} 2$, however being insignificant, may be to keep rumen $\mathrm{pH}$ low for partial disassociation of calcium soaps before completing dissociated in the acidic condition of the abomasums (Jenkins and Palmquist, 1984).

\section{Leptin concentration:}

During fattening period Leptin concentration increased with age progress in both groups, but it showed higher trend in G2 than in G1. The overall mean of Leptin concentration during this period was lower $(\mathrm{P}<0.05)$ in $\mathrm{G} 1(3.9 \pm 0.8 \mathrm{ng} / \mathrm{ml})$ than in G2 $(5.0 \pm 0.6 \mathrm{ng} / \mathrm{ml})$. Pattern of Leptin concentration was almost similar in both studied groups, except in G2 where, Leptin concentration started to be decreased by the end of the experiment while, continued increasing in G1 (Figure 5). This trend in both experimental groups agreed with the findings of Kawakita et al. (2001) on Japanese Black steers.

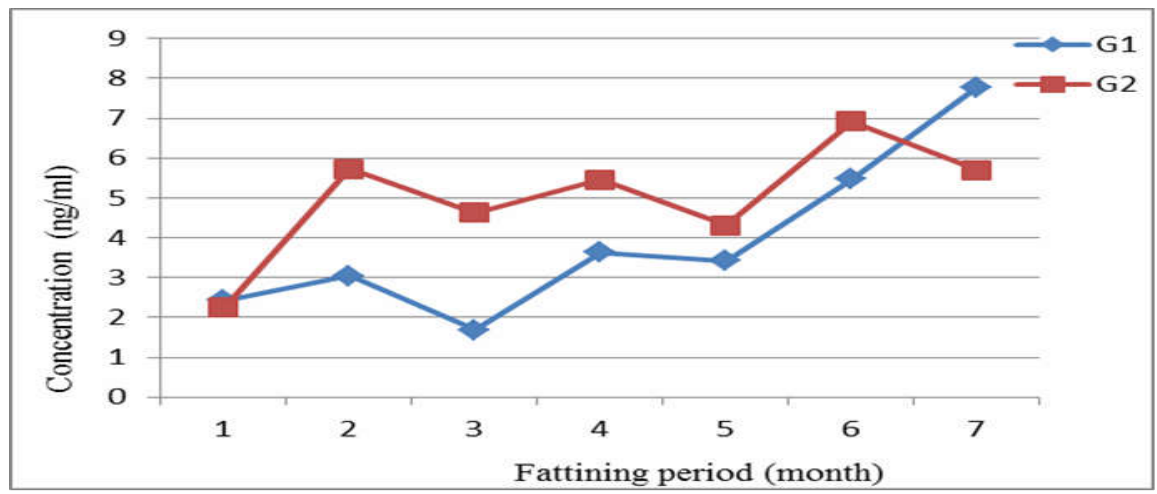

Figure 5. Leptin concentration in buffalo calves fed on concentrate feed mixture (G1) and concentrate feed mixture supplemented with protected fat (G2)

The relation between feeding on diets containing fats and Leptin concentration showed wide variation among the previous works. However, the present result came in agreement with the findings of Gillis et al. (2004) and Tokuda et al. (2008) who reported that Leptin concentration was higher in plasma of calves fed on diet containing fat compared to control group, but it is contradicted with the findings of Block et al. (2003); Garcia et al. (2003) and Villalobos et al. (2007) who reported that feeding growing beef heifers on diet containing up to $7 \%$ fat had no effect on peripheral blood concentration of Leptin.

Increasing Leptin concentration in G2 may be due to the stimulating effect of fat diet on plasma insulin (Williams and Stanko, 1999), which positively stimulates plasma Leptin secretion (Wegner et al., 2001 and Tokuda et al., 2008) to regulate energy homeostasis. 


\section{Correlation Coefficients:}

Correlation coefficients among some of the studied traits differed between G1 and G2 in trend and values. Correlation coefficient between Leptin and IGF-1 was positive in G1, while it was negative in G2. A reverse trend was observed between IGF-1 and ADG, which was negative in G1 $(\mathrm{P}<0.05)$, while positive in $\mathrm{G} 2$. Correlation values between Leptin and ADG as well as BW and ADG were negative in both studied groups (Table 3).

The significant difference $(\mathrm{P}<0.05)$ in correlation coefficient between Leptin and BW may be due to the higher concentration of Leptin in the peripheral blood plasma of G2 compared to G1 (Figure 5). Negative correlation between Leptin and ADG in both groups (Table 3) during is supported by the findings of Altmann et al. (2006), who recorded negative relationship between Leptin and average daily gain. IGF-1 and Leptin in G2, came in agreement with the findings of Garcia et al. (2003) and Brandt et al. (2007) in cattle, who referred this trend to either the negative correlation between Leptin and both of GH and IGF-1 or inhibiting effect of Leptin on hepatic IGF-1 secretion. There are another reason, which may be due to the stress effect of fat on liver function that leads to decrease of IGF-1 secretion (Villalobos et al., 2007).

Positive correlation coefficient between IGF-1 in G1 and the negative corresponding value of $\mathrm{G} 2$, may be resulted from the negative correlation between IGF-1 and Leptin in G2.

Table 3. Correlation coefficients among BW, ADG, circulating concentrations of Leptin and IGF-1 of G1 and G2 of Egyptian buffalo calves during fattening period

\begin{tabular}{lccccc}
\hline Variable & Group & $\begin{array}{c}\text { Leptin } \\
(\mathrm{ng} / \mathrm{ml})\end{array}$ & $\begin{array}{c}\text { IGF-1 } \\
(\mathrm{ng} / \mathrm{ml})\end{array}$ & ADG $(\mathrm{kg})$ & BW (kg) \\
\hline Leptin $(\mathrm{ng} / \mathrm{ml})$ & G1 & 1 & 0.681 & -0.568 & $0.836^{*}$ \\
IGF-1 (ng/ml) & & & 1 & $-0.762^{*}$ & 0.524 \\
ADG $(\mathrm{kg})$ & & & & 1 & -0.269 \\
BW $(\mathrm{kg})$ & & & & 1 \\
& & & -0.489 & -0.406 & 0.658 \\
Leptin $(\mathrm{ng} / \mathrm{ml})$ & $\mathrm{G} 2$ & 1 & 1 & 0.494 & -0.357 \\
IGF-1 (ng/ml) & & & & 1 & -0.018 \\
ADG $(\mathrm{kg})$ & & & & & 1 \\
BW $(\mathrm{kg})$ & & & &
\end{tabular}

\section{Carcass traits:}

There are no significant differences between G1 and G2 concerning slaughter weight, empty body weight, hot carcass, weight dressing percentage, boneless meat percentage, offal percentage, proportion of hind and fore quarters, while there was a significant difference between the two studied groups concerning the percentages of high priced cuts, which was higher $(\mathrm{P}<0.01)$ in $\mathrm{G} 2$ than in $\mathrm{G} 1$ (Table 4$)$.

The present result of dressing percentage (DP) agrees with the findings of Nada (2003); Abd Al-Rahman (2005) and Abo-Donia and Ibraheim (2008) reporting DP 
between 47.1 and $58.6 \%$ with no effect of feeding fat diet on this trait. Percentage of boneless meat of buffalo bulls reported by Nada (2003) and Abd Al-Rahman (2005) ranged between 36.28 and $43.0 \%$ calculated out of slaughter weight. These results were higher than that reported in the present study, which may be due to lower slaughter weight in the present study, which may lead to higher percentage of bone. Meanwhile, it is close in trend with the finding of Nada (2003), reporting fed Egyptian buffalo bulls on protected fat supplemented diet had no effect on boneless meat percentage.

Table 4. Carcass traits (Mean \pm SE) of Egyptian buffalo calves fed concentrate mixture (G1) and concentrate feed mixture supplemented with protected fat (G2)

\begin{tabular}{lccc}
\hline Trait & G1 & G2 & P-value \\
\hline Slaughter weight $(\mathrm{kg})$ & $385.0 \pm 7.4$ & $397.0 \pm 4.9$ & 0.223 \\
Empty body weight $(\mathrm{kg})$ & $343.0 \pm 3.7$ & $357.0 \pm 4.5$ & 0.052 \\
Hot carcass weight $(\mathrm{kg})$ & $197.0 \pm 4.9$ & $197.0 \pm 6.5$ & 0.937 \\
DP $(\%)^{1}$ & $51.17 \pm 0.3$ & $49.78 \pm 1.14$ & 0.289 \\
BLM (\%) & $35.6 \pm 0.8$ & $38.3 \pm 1.4$ & 0.145 \\
High priced cuts*1 $(\%)^{r}$ & $23.78 \pm .24$ & $25.75 \pm .49$ & 0.012 \\
Expletive fat** (\%) $^{{ }^{r}}$ & $1.96 \pm .08$ & $2.10 \pm .16$ & 0.478 \\
Offal (\%) & $29.07 \pm 0.38$ & $29.20 \pm 0.16$ & 0.735 \\
\hline
\end{tabular}

1 Calculated as a proportion of slaughter weight, 2 proportion of hot carcass weight. * calculated as sum of round, fillet, sirloin and fore ribs, ** calculated as sum of heart fat, kidney fat, intestinal fat, abdominal and other fat

The obtained significant increase $(\mathrm{P}=0.012)$ in high priced cuts of $\mathrm{G} 2$ than $\mathrm{G} 1$ is in accordance with the findings of Abo-Donia and Ibraheim (2008), while contradicted with the results of Nada (2003) who reported no effect of feeding ration contained Ca-SFA on high priced cuts percentage.

The insignificant difference between the two groups concerning expletive fat percentage is in agreement with the findings of Garcia et al. (2003) in beef heifers and Nada (2003) in buffalo bulls. This however disagrees with the finding of ElBedawy et al. (2004) recording higher total body fat for Baladi bulls fed fat ration. Abd Al-Rahman (2005) and Abo -Donia and Ibrahim (2008) found that kidney fat were significantly higher with feeding Ca-SFA than control group. Differences in this respect among authors most probably attributed to the difference in slaughter weights.

\section{Meat Traits:}

Obtained results of the physical traits indicated no significant difference between the two studied groups in respect to percentages of bone, meat and fat. The nonsignificant difference between the two groups is extended also to color density, cooking loss $\%$ and shear force values (Table 5). Moreover, no significant difference was observed between the two groups in chemical analysis except in chemical fat percentage which was higher $(\mathrm{P}=0.04)$ in $\mathrm{G} 2$ relative to $\mathrm{G} 1$. 
Table 5. Physical and chemical characteristics (mean $\pm \mathrm{SE}$ ) of Longissimus dorsi muscle in Egyptian buffalo calves under control (G1) and fat supplement (G2) feed ( $n=4 /$ group)

\begin{tabular}{lccc}
\hline Trait & G1 & G2 & P-value \\
\hline $\begin{array}{c}\text { Physical traits } \\
\text { Best ribs components \% }\end{array}$ & & \\
Lean & $59.72 \pm 1.4$ & $57.1760 \pm 6.1$ & 0.702 \\
Fat & $16.63 \pm 3.9$ & $13.32 \pm 3.3$ & 0.542 \\
Bone & $26.62 \pm 1.4$ & $26.30 \pm 2.7$ & 0.922 \\
& & & \\
Color density & & & \\
Brightness ( L*) & $37.9 \pm 1.3$ & $36.16 \pm .97$ & 0.329 \\
Redness (a*) & $17.01 \pm .36$ & $17.05 \pm .75$ & 0.965 \\
$\quad$ Yellowness(b*) & $4.31 \pm .37$ & $3.82 \pm .58$ & 0.506 \\
Cooking loss (\%) & $45.06 \pm .46$ & $43.44 \pm 1.2$ & 0.256 \\
Shear force (kg/ f/ 0.5 inch) & $4.03 \pm .32$ & $4.72 \pm .51$ & 0.300 \\
Chemical composition (\%) & & & \\
Moisture & $76.28 \pm .59$ & $75.50 \pm .46$ & 0.339 \\
Protein & $21.21 \pm .16$ & $20.91 \pm .27$ & 0.395 \\
Fat & $1.13 \pm .14$ & $1.60 \pm .10$ & 0.040 \\
Collagen & $1.66 \pm .07$ & $1.24 \pm .19$ & 0.095 \\
\hline
\end{tabular}

$L^{*}\left(0=\right.$ black, $100=$ white; $a^{*}$ redness $/$ greenness (positive values $=$ red, negative values $=$ green; $b^{*}$ yellowness/blueness; (positive values $=$ yellow, negative values $=$ blue).

Results of physical components of best ribs are in agreement with the findings of Nada (2003) and Abo-Donia and Ibraheim (2008) under feeding Egyptian buffalo bulls on ration supplemented with fat. Meanwhile, results of chemical analysis disagree with the finding of Nada (2003), Garcia et al. (2003) and Abo-Donia and Ibraheim (2008) reporting that feeding heifers or buffalo bulls on diet contained fat had no effect on dry matter and fat percentage of eye muscle contents $v s$. decreasing in protein content.

Increasing intramuscular fat content of eye muscle in G2 most probably attributed to increasing in plasma Leptin concentration (Kawakita et al., 2001; and Gillis et al., 2004), which may resulting in improving marbling score (Mcfadin et al., 2003) of meat.

\section{CONCLUSION}

In conclusion, growth curve of Egyptian buffalo calves between 8 and 24 months showed exponential increase up to $23^{\text {rd }}$ month of age before showing descending trend. This was accompanied with high level of IGF-1 concentration, while Leptin concentration in the peripheral blood started to increase from the $20^{\text {th }}$ month of age. Supplying ration with protected fat during fattening period (256 to $400 \mathrm{~kg}$ ) had no effect on growth, carcass, and meat traits. 


\section{REFERENCES}

Abd Al-Rahman S. A.M., 2005. Performance of buffalo calves fed rations containing different sources and levels of full fat seeds. M.Sc. Thesis. Faculty of Agriculture, Cairo University, Egypt.

Abd El-Aziz N.A.E., 2006. Effect of using some growth stimulators and Vitamin $\mathrm{C}$ on growth and reproductive performance of Egyptian Buffalo calves under different climatic Conditions. Ph.D. Thesis, Faculty of Agriculture, Al-Azhar University, Egypt.

Abo-Donia F.M. and S. A. Ibraheim, 2008. Effect of feeding different levels of calcium salts of fatty acids on digestibility, body dimension and carcass characteristics of fattening Buffalo bulls. Egyptian Journal of Animal Production, 45: $171-186$.

Altmann M., H. Sauerwein and E. von Borell, 2006. Plasma Leptin in growing lambs as a potential predictor for carcass composition and daily gain. Journal of Meat Science, 74: 600-604.

Anderson P. T., W. G. Bergen, R. A. Merkel, W. J. Enright, S. A. Zinn, K. R. Refsal, and D. R. Hawkins, 1988. The relationship between composition of gain and circulating hormones in growing beef bulls fed three dietary crude protein levels. Journal of Animal science, 66:3059-3067

Appo Rao V., G. Thulasi and S. Wilfred Ruban, 2009. Meat quality characteristics of non descript buffalo as affected by age and sex. World Applied Science Journal 6 (8):1058-1065.

Baker R. L., A. J. Peterson, J. J. Bass, N. C. Amyes, B. H. Breier, and P. D. Gluckman, 1991. Replicated selection for insulin-like growth factor-I and body weight in mice. Theor. Appl. Genet. 81:685-692.

Barkawi A.H., Amal. K. El-Asheeri, Y.M. Hafez, M.A. Ibrahim and M.M. Ali, 2009. Growth and carcass characteristics of lambs in relation to plasma IGF-1 and some histological traits of Longissimus dorsi and Biceps femoris as affected by breed and age at slaughter. Journal of Livestock Science, 124, 914.

Bassiouni M.I., E.M. Abd El-Raouf, and M.K. Mohsen, 2000. Performance of growing buffalo calves supplemented with fishmeal or soybean and/or molasses. Proc. $3^{\text {rd }}$ all Africa conf. Anim. Agric. \& $11^{\text {th }}$ conf. Egyptian Soc. Anim. prod., Alexandria. Egypt, 6-9 November, 229-236.

Bendary M.M., I. A. Abu-Selim, M.R.M. Moutafa, A. M. Mahmoud and A.E.M. Khinizy, 1994. Performance of fattening Buffalo calves fed different levels of fat for two different Periods. Egyptian Journal of Animal Production, 31:613 626.

Block S.S., J.M. Smith, R.A. Ehrhardt, R. P. Diaz, M. E. Rhoads, M. E. Amburgh and Y. R. Boisclair, 2003. Nutritional and developmental regulation of plasma Leptin in dairy cattle. Journal of Dairy Science, 86: 3206-3214.

Brandt M. M., D. H. Keisler, D. L. Meyer, T. B. Schmidt and E. P. Berg, 2007. Serum hormone concentrations relative to carcass composition of a random allotment of commercial-fed beef cattle. Journal of Animal Science, 85:267275 . 
Chilliard Y., C. Delavaud and M. Bonnet, 2005. Leptin expression in ruminants: nutritional and physiological regulations in relation with energy metabolism. Journal of Domestic Animal Endocrinology., 29: 3-22.

CIE (Commission International de l'E'clariage), 1976. official recommendations on uniform colour spaces. Colour difference equations and metric colour terms, Suppl. No. 2. CIE Publication No. 15 Colourimetry, Paris.

Connor E. E., S. M. Barao, A. S. Kimrey, A. B. Parlier, L. W. Douglass and G. E. Dahl, 2000. Predicting growth in Angus bulls: the use of GHRH challenge, insulin-like growth factor-I, and insulin-like growth factor binding proteins. Journal of Animal Science, 78:2913-2918.

Cronje P.B., 2002. Ruminant physiology, digestion, metabolism, growth and reproduction. CABI, USA, P 178-202.

Daix M., C. Pirotte, J.L. Bister, F. Wergifosse, C. Cuvelier, J.F. Cabaraux, N. Kirschvink, L. Istasse and R. Paquay, 2008. Relationship between leptin content, metabolic hormones and fat deposition in three beef cattle breeds. The Veterinary Journal, 177: 273-278.

El-Ashry M. A., A. Z. El-Basiony, H.S. Soliman and H.M. El-Sayed, 1996. Effect of feeding inedible wheat flour and pasta industry waste in combination with broiler on the performance and blood serum parameters of buffalo calves. Egyptian Journal of Animal Production, 41: 91-102.

El-Bedawy T. M., I. A. Gommaa, S. M. Allam and F. M. Abo-Donia, 2004. Production of calcium salts of fatty acid from soap-stock on semi industrial scale and its use in finishing rations of Frisian bulls. Egyptian Journal of Animal Production, 41: 61 -71.

El-Bedawy T.M., M.A.I. Salem and E.A. Bader, 1996. Effect of dietary fat on growth performance and carcass characteristics of finishing bulls. Egyptian journal of Animal Production, 3: 103-111.

El-Naggar A. S. A, 1998. Metabolic profile and hormones in blood of buffaloes and cattle in relation to growth patterns. Ph.D. Thesis. Faculty of Agriculture, Cairo University, Egypt.

Fryburg D. A. 1994. Insulin-like growth factor I exerts growth hormone and insulin-like actions on human muscle protein metabolism. Journal of Animal Physiology, 267: 331-336.

Garcia M. R., M. Amstalden, C. D. Morrison, D. H. Keisler and G. L. Williams, 2003. Age at puberty, total fat and conjugated linoleic acid content of carcass, and circulating metabolic hormones in beef heifers fed a diet high in linoleic acid beginning at four months of age. Journal of Animal science, 81:261-268.

Gassman K. J., D. C. Beitz, F. C. Parrish and A. Trenkle, 2000. Effects of feeding calcium salts of conjugated linoleic acid to finishing steers. Journal of Animal Science, 78(Suppl. 1):275-276. (Abstr.)

Gigli S., A. Carreta, S. Failla and F. Napolitano, 1993. Meat production in Italian male buffaloes reared with two nutritive levels and slaughtered at 4 different ages. IN VITA performance carcass characteristics and meat quality. Prospects of buffalo production in the Mediterranean and the Middle East European Ass. Journal of Animal Production. No.62, p. 124.

Gillis M. H., S. K. Duckett, J. R. Sackmann, C. E. Realini, D. H. Keisler and T. D. Pringle, 2004. Effects of supplemental rumen-protected conjugated linoleic 
acid or linoleic acid on feedlot performance, carcass quality, and leptin concentrations in beef cattle. Journal of Animal science, 82:851-859.

Hess B. W., G. E. Moss and D. C. Rule, 2008. A decade of developments in the area of fat supplementation research with beef cattle and sheep. Journal of Animal Science, 86:188-204.

Jenkins T.C. and D. L. Palmquist. 1984, Effect of fatty acids or calcium soaps on rumen or total nutrition digestibility of dairy rations. Journal of Dairy Science, 67:971.

Kawakita Y., H. Abe, K. Hodate, A. Iguchi, M. Kobayashi, T. Mori, K. Kasai, Y. Tanai, Y. Kanbe, H. Mashiyama, T. Asadaand and T. Miyashige, 2001. The relation between plasma leptin concentrations and carcass lipid contents in Japanese Black steers. Journal of Livestock Production Science, 73: 25-34.

Lee C. Y., D. M. Henricks, G. C. Skelley and L. W. Grimes, 1990. Growth and hormonal response of intact and castrate male cattle to trenbolone acetate and estradiol. Journal of Animal Science, 68:2682-2689.

Leon H.V., J. Hernandez-Ceron, D.H. Keisler and C.G. Gutierrez, 2004. Plasma concentration of leptin, insulin-like growth factor-I, and insulin in relation to changes in body condition score in heifers. Journal of Animal Science, 82:445451

Mahmoudzadeh H., H. Fazaeli, I. Kordnejad and H.R. Milzaei, 2007. Response of male buffalo calves to different levels of energy and protein in finishing diets. Journal of Biological Science, 10(9): 1398- 1405.

Mandal A.B., S.S. Paul and N.N. Pathak, 2003. Nutrient requirements and feeding of buffaloes and cattle. International book distributing co, India, $209 \mathrm{pp}$.

Mcfadin E.L., D.H. Keisler, T.B. Schmidt, C.L. Lorenzen and E.P. Berg, 2003. Correlations between serum concentrations of Leptin and beef carcass composition and quality. Journal of Muscle Foods, 14: 81-87.

Nada S. M. A., 2003. Effect of some feeding regimes on meat production of Buffalo calves. M.Sc. Thesis, Faculty of Agriculture, Cairo University, Egypt.

Nkrumah J. D., D. H. Keisler, D. H. Crews, Jr., J. A. Basarab, Z. Wang, C. Li, M. A. Price, E. K. Okine and S. S. Moore, 2007. Genetic and phenotypic relationships of serum Leptin concentration with performance, efficiency of gain, and carcass merit of feedlot cattle. Journal of Animal Science, 85:21472155 .

Nour El-Din A.N.M., S.Z. El-Zarkouny, H. Ghobashy, E.I. Abdel-Gawad and D.J. Kesler, 2009. Growth, haematological and biochemical responses of growing lambs injected with growth hormone and supplemented with calcium soaps of fatty acids. South African Journal of Animal Science, 39:65- 68.

NRC, 2000. Nutrient Requirement of beef cattle. National Research Council, National Academy, Seventh Revised Edition: Update 2000.Cited in http://www.nap.edu/catalog/9791.html.

Owens F. N. and B. A. Gardner, 1999. A review of the impact of feedlot management and nutrition on carcass measurements of feedlot cattle. Proceedings of the American Society of Animal Science.1-18.

Ragab M.T., M.Y.H. Darwish and A.G.A. Malek, 1966. Meat production from Egyptian buffaloes, 1- developmental changes and dressing percentage in a group of buffalo males. Journal of Animal Production. U.A.R., 6: 9-30. 
Rehfeldt, C; I. Fieder, and N. C. Stickland, 2004. Number and size of muscle fibres in Relation to Meat Production. In: "Muscle development of livestock animals" (Te Pas, M.F.W.; Everts, M.E. and Haagsman, H.P.), CABI, USA, pp: $1-32$.

Sami A.S. 2001. Performance of fattening bulls fed diets supplemented with protected fat. Ph.D. Thesis, Faculty of Agriculture, Cairo University, Egypt.

Shackelford S.D., T.L. Wheeler and M. Koohmaraie, 1999. Tenderness classification of beef: ii. Design and analysis of a system to measure beef Longissimus shear force under commercial processing conditions. Journal of Animal Science, 77:1474-1481.

Shimizu M., C. Webster, D.O. Morgan, H.M. Blau and R.A. Roth. 1986. Insulin and insulin like growth factor receptors and response in cultured human cells. American Journal of Physiology, 251: 611-615.

Squires E. J. 2003. Applied animal endocrinology. CABI, USA, 230 pp.

Te-Pas M.F.W., M.E. Everts and H.P. Haagsman. 2004. Muscle development of livestock animals, CABI, USA, 399 pp.

Thomas M.G., R.M. Enns, D.M. Hallford, D.H. Keisler, B.S. Obeidat, C.D. Morrison, J.A. Hernandez, W.D. Bryant, R. Flores, R. Lopez and L. Narro. 2002. Relationships of metabolic hormones and serum glucose to growth and reproductive development in performance-tested Angus, Brangus, and Brahman Bulls. Journal of Animal science, 80: 757-767.

Tokuda T.; E.A. Orden, A.N. Barrio, R.M. Lapitan, C. Delavaud, Y. Chilliard, T. Fujihara, L.C. Cruz, H. Homma and Y. Kanai. 2007. Effects of species and sex on plasma hormone and metabolite concentrations in crossbred Brahman cattle and crossbred water buffalo. Journal of Livestock Science, 107: 244252.

Tokuda T. B., C. Delavaud, Y. Chilliard and T. Fujihra. 2008. Plasma Leptin, feed intake and body fat accumulation in fattening castrated male and female lambs. Animal Science Journal, 79:58-67.

Villalobos B. D., I. G. Tornad, G. Shroeder, E. E. Salado, G. Gagliostro, C. Delavaud, Chilliard, Y. and Lacau-Mengido, I. M. 2007. Effect of fat supplementation on leptinLeptin, insulin-like growth factor I, growth hormone, and insulin in cattle. The Canadian Journal of Veterinary Research, 71:218-225.

Wegner, J., P. Huff, P., C. P. Xie, F. C. P., Schneider, F., F. Teuscher, P. S. F., Mir, Z. P. S., Mir, E. C. Z., Kazala, E. C., R. Weselake, R. and K. Ender, K. 2001. Relationship of plasma Leptin concentration to intramuscular fat content in beef from crossbred Wagyu cattle. Candian . Journal of Animal Science, 81: 451-457.

Weniger J., D. Sfeinhauf and G.H. Pahl. 1963. Muscular topography of carcasses. BLV. Verlagsgessellschaft, Muenche, Germany. 143pp.

Williams, G. L. and R. L. Stanko,. 1999. Dietary fats as reproductive nutraceuticals in beef cattle. Proceedings of the American Society of Animal Science, 1-12.

Yilmaz A., M. E. Davis and R. C. M. Simmen, 2004. Estimation of (co)variance components for reproductive traits in Angus beef cattle divergently selected for blood serum IGF-1 concentration. Journal of Animal Science, 82:22852292. 
Zieb D.A., A.M. Amstalden and G.L. Williams. 2005. Regulatory roles of Leptin in reproduction and metabolism: A comparative review. Domestic Animal Endocrinology, 29: 166-185. 


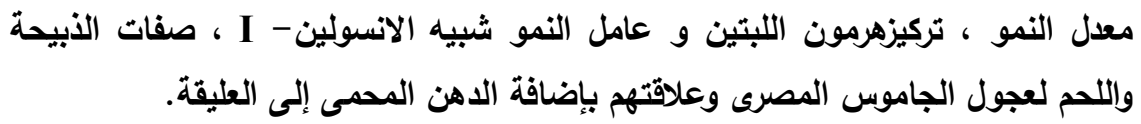

سالم محمد سالم ، آمال كمال العشيري، رحاب ناجي إبراهيم

قسم الإنتاج الحيوانسي ، كلية الزراعة، جامعة القاهز ، شارع الجامعة، الجيزة

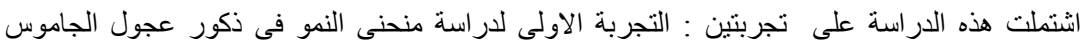

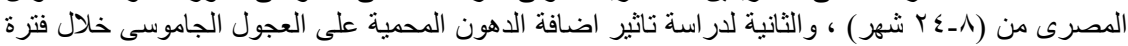

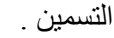

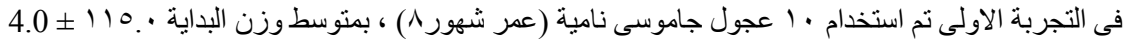

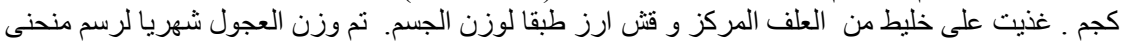

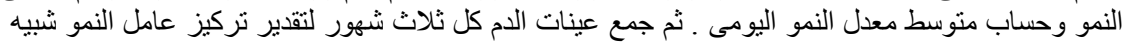

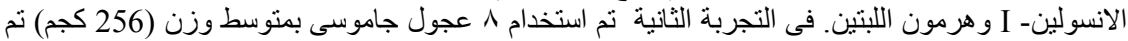

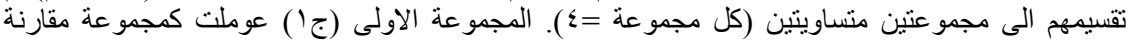

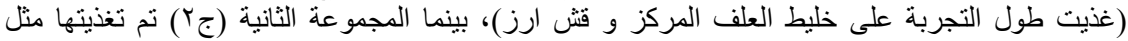
المجمو عة الاولى بالاضافة الى الدهون المحمية (بمتوسط و

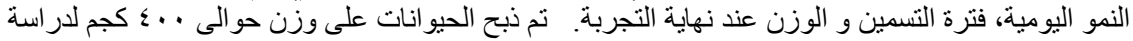

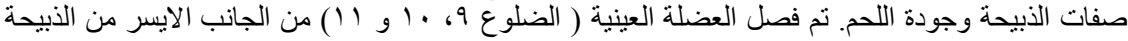

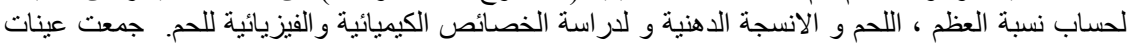

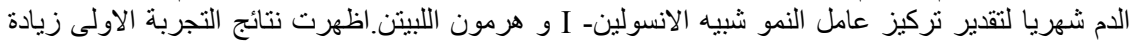

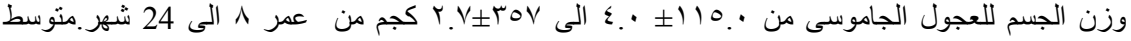

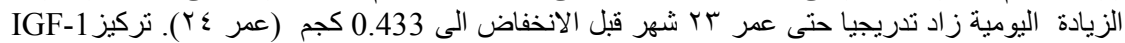

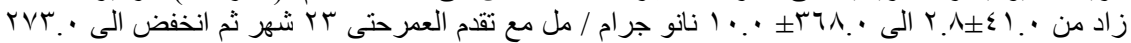

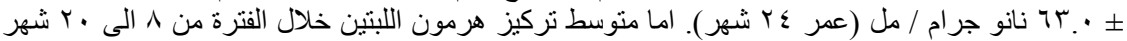

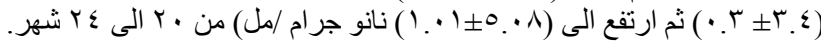

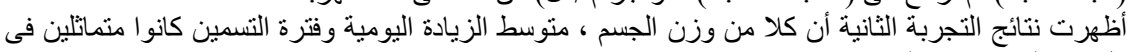
كل من المجمو عتين لتكون • • .

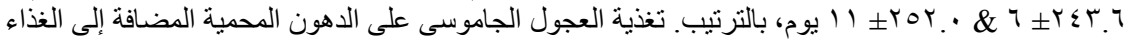

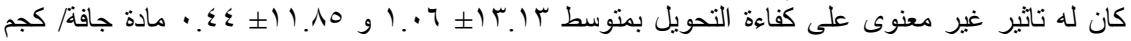

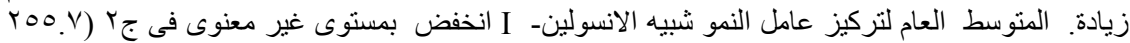

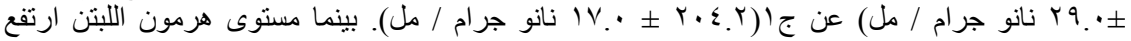

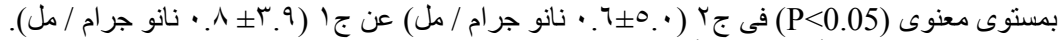

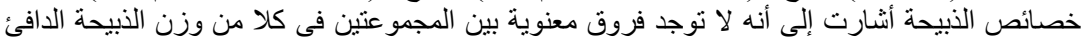

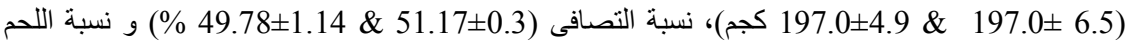

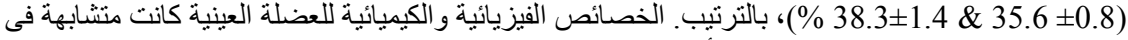

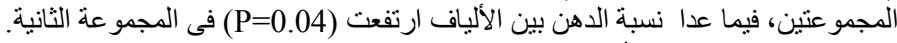

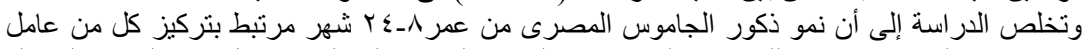

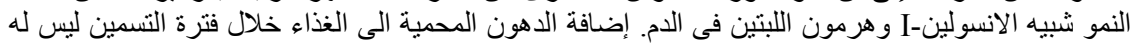

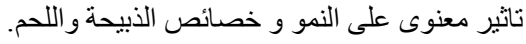

